\title{
The Impact Of Corporate Governance And The Sarbanes-Oxley Act On CEO Compensation
}

Mahmoud M. Nourayi, Ph.D., Loyola Marymount University, USA Lawrence Kalbers, Ph.D., Loyola Marymount University, USA Frank P. Daroca, Ph.D., Loyola Marymount University, USA

\begin{abstract}
This paper examines the effects of corporate governance on CEO compensation in light of regulatory controls introduced by the Sarbanes-Oxley Act of 2002 (SOX). The influence of economic and corporate governance variables on incentive-based CEO compensation are considered, using cross-section time-series panel data that includes multiple observations for the years 1999 to 2005. As expected, sales, firm performance (returns), and CEO age were found to positively affect the incentive components of CEO compensation. CEO duality, board size, and the percentage of outside directors had a significant influence on CEO compensation in the preSOX, but not post-SOX, period. The influences of these three variables in the pre-SOX period were not in the expected directions. Stratification of our sample into two groups by size reveals similarities and differences between smaller and larger firms. For both groups, economic determinants are more dominant than corporate governance variables as determinants of incentive-based CEO compensation. We find differences in the pattern and significance of variables between the smaller and larger firms, particularly for corporate governance variables, pre- and post-SOX. These results suggest that the effectiveness of corporate governance mechanisms may vary by size of company.
\end{abstract}

Keywords: CEO Compensation and Corporate Governance; CEO Compensation and Sarbanes-Oxley Act; SOX; Corporate Governance and Sarbanes-Oxley Act

\section{INTRODUCTION}

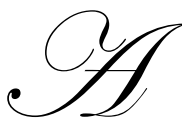

$s$ the level of CEO compensation has risen over the years, research in this subject has grown concomitantly. Investors, regulators, and researchers continue to have an interest in how CEO compensation is determined and disclosed. Boards of directors, as representatives of shareholders, determine CEO compensation. Corporate governance is viewed as an important aspect of the ability of boards of directors to act on behalf of shareholders in a way that properly aligns the interests of CEOs and shareholders in compensation contracts.

The theoretical foundation of such work lies with principal-agency theory (Ross, 1973; Jensen and Meckling, 1976; Grossman and Hart, 1983), which in turn can be traced to Berle and Means (1932). The theory describes the separation of firm ownership (principal) and choices by management (agent). Researchers have buttressed the principal/agent disconnect along several dimensions: demographics (Young and Buchholtz, 2002), stock-based compensation (Jensen, 2005) and its relationship to earnings restatement (Cheng and Farber, 2008), CEO relationships (Brown et al., 2009; Larcker et al., 2005), risk (Guay, 1999), board independence (Kumar and Sivaramakrishnan, 2008), industry regulation (Agrawal et al., 1991; Anderson et al., 2000; Arya and Sun, 2004; Bryan and Hwang, 1997), voluntary reporting on internal control (Owusu-Ansah and Ganguli, 2010), and firm size (Lambert et al., 1991). 
One reaction to perceived principal-agent imbalance is the rise of the corporate governance movement that, simply stated, attempts to strengthen stakeholder input by reducing restrictions imposed by management. Particular corporate governance structures and mechanisms are thought to increase the likelihood that boards will act in the best interest of shareholders. This is expected to result in positive outcomes for shareholders, such as appropriate levels of CEO compensation, improved performance, and increased firm value.

Ever-increasing CEO compensation and the collapse of Enron and WorldCom in 2001 are two instances of principal-agent asymmetry perceived by the public. A consequence of the latter events was the passage of the Sarbanes-Oxley Act of 2002 (SOX) $^{1}$ that tacitly embraced optimal contracting (see below). For example, the passage of SOX and related listing requirements approved by the United States Securities and Exchange Commission (SEC) require a range of "good" corporate governance practices.

The purpose of this paper is to examine the relationship between the CEO compensation and various economic and governance variables and to discern the influence of these variables over time as affected by the Sarbanes-Oxley Act. ${ }^{2}$ Our analyses are based on the cross-section, time-series panel data for a set of companies for the period 1999-2005 to examine incentive components of CEO compensation. As such, we curtail variability of the results that may stem from changes in the $\mathrm{CEO}$ over our examination period.

In the next section we present the review of literature related to influence of corporate governance on CEO compensation and evidence related to the effects of SOX. The third section covers the research hypotheses and methodology. Sample selection process and information about our data and the research method appear in section four. Then we present the analyses and results in the fifth section. In the final section of this paper we summarize our findings and discuss limitations and opportunities for further investigations.

\section{LITERATURE REVIEW}

The relationship between corporate governance and executive compensation, firm performance, and other important corporate outcomes has long been of interest to scholars. Good corporate governance, including the appropriate mix of directors on the board and key board committees, is an important component in monitoring management for shareholders. Conversely, poor corporate governance is likely to increase "managerial power" (Bebchuk and Fried, 2003, 2004; Grinstein and Hribar, 2004; Fahlenbrach, 2009). For example, outside, independent directors are considered to be better situated to make unbiased decisions about executive compensation (see, e.g., Fama, 1980; Fama and Jensen, 1983). However, outside directors may be selected and influenced by management, and may also lack the time or interest to properly monitor management (Jensen, 1993). Weak corporate governance may allow opportunistic behavior and entrenchment by management (Bebchuk and Fried, 2004; Bebchuk et al., 2009).

As noted by Brown et al. (2009, p. 2), the arguably competing hypotheses are the "optimal contracting approach," based on the premise that the value of the firm is maximized if executive compensation is designed to minimize agency costs, and the "managerial power approach" as proposed by Bebchuk et al. (2002). The managerial power approach states that CEO influence over their pay might impose substantial shareholder cost "beyond the excess pay executives receive-by diluting and distorting managers' incentives and thereby hurting corporate performance" (Bebchuk and Fried, 2003, p. 72; also see Bebchuk and Fried, 2004).

Several studies have found declines in incentive compensation and risk Post-SOX (Cohen et al., 2009), earnings management in relation to SOX (Cohen et al., 2004; Carter et al., 2006), and tenure, turnover and risk aversion (Wang et al., 2010). Li and Srinivasan (2010) demonstrated that founding directors earn more than nonfounders, but cash compensation is unrelated to corporate earnings (Shaw and Zhang, 2010). Likewise, Larcker et

\footnotetext{
${ }^{1}$ Public Company Accounting Reform and Investor Protection Act of 2002 (H.R. 3763).

${ }^{2}$ Many of these specific regulations were actually proposed by self-regulatory organizations (NYSE and NASDAQ) and were approved by the U.S. Securities and Exchange Commission (SEC) in 2003. Following Chhaochharia and Grinstein (2009), we treat 2003 as the first year Post-SOX (i.e., after Sarbanes-Oxley was passed and these regulations were likely to be followed by most corporations).
} 
al. (2010) found a negative correlation between CEO compensation and abnormal returns, and others found strong evidence of CEO compensation and weak corporate governance (Core et al., 1999). Fahlenbrach (2009) notes that weaker governance may serve the interests of shareholders and the CEO through substitution of governance mechanisms with higher levels of performance pay.

The structure and activities of the compensation committee has been of obvious interest to researchers and regulators. Although SOX requires 100 percent outside, independent directors on compensation committees, regulations and best practices pushed companies toward this goal much earlier (Andersen and Bizjak, 2003). Prior research reveals limited impact of the membership attributes of the compensation committee on CEO compensation (Andersen and Bizjak, 2003; Petra and Dorata, 2008).

One purpose of SOX was to require certain "best" practices for all public companies in order to improve corporate governance and board monitoring of management. Before the passage of SOX, many corporations had already adopted some, or all, of these best practices. There is some evidence that SOX has had the intended impact. For example, prior research demonstrates that companies with poorer corporate governance pre-SOX had larger reductions in CEO compensation post-SOX than those with better corporate governance practices (Chhaochharia and Grinstein, 2009). More specifically, Chhaochharia and Grinstein (2009) found that, after implementation of SOX requirements, CEO compensation dropped significantly more for those companies that had voluntarily adopted fewer of these requirements prior to SOX (non-compliant companies) compared with those companies that had adopted more of these requirements prior to SOX (compliant companies).

Carter et al. (2009) suggest the impact of pre-SOX "upward" earnings management was counteracted by more emphasis on earnings changes in bonus contracts post-SOX to reduce the effect of earnings management. These studies strongly suggest that mandated improvements in corporate governance can lead to improved monitoring by boards of directors.

\section{RESEARCH HYPOTHESES AND METHODS}

The purpose of this study is to examine the impact of corporate governance on CEO compensation pre- and post-SOX. Our examination is based on the comparison of CEO compensation as affected by the enactment of the SOX. We anticipate CEO compensation contracts to be influenced by the corporate governance structure as new regularity measures were introduced while economic determinants of such contracting remain the same over the examination period.

In this section we present the general model for estimating the CEO compensation. Then we modify the model to include governance variables we expect to have differential influence as we compare pre and post- SOX compensation data.

Estimation of CEO Compensation Model. Many executive compensation studies have analyzed the payperformance relationship utilizing a model generally specified as follows:

$\mathrm{PAY}_{\mathrm{it}}=\alpha+\beta\left(\mathrm{SIZE}_{\mathrm{it}}\right)+\gamma\left(\right.$ PERFORMANCE $\left._{\mathrm{it}}\right)+\varepsilon_{i t}$

where Pay $y_{i t}$ is the CEO compensation of firm i, year $t$, SIZE $_{i t}$ is the size of firm i, year t, PERFORMANCE ${ }_{i t}$ is an observable performance measure of firm $\mathrm{i}$, year $\mathrm{t}$, and $\varepsilon_{i t}$ is the error term.

Economic Determinants of CEO Compensation. Certain economic outcomes should be related to the activities of management. Therefore, CEO compensation should be a function of those economic determinants. We expect greater CEO compensation for larger, more complex, and more profitable firms.

We expand the basic compensation model (1) to include governance variables as shown below:

$\ln \left(\mathrm{PAY}_{\mathrm{it}}\right)=\alpha+\beta \ln \left(\mathrm{SIZE}_{\mathrm{it}}\right)+\gamma\left(\mathrm{PERFORMANCE}_{\mathrm{it}}\right)+\lambda\left(\mathrm{GOVERNANCE}_{\mathrm{it}}\right)+\varepsilon_{i t}$ 
Corporate Governance and CEO Compensation. In addition to economic determinants, corporate governance may have a positive or negative influence on contracting with the CEO. Prior research suggests that CEO compensation is greater when the CEO is also the chairman of the board of directors (Core et al., 1999; Grinstein and Hribar, 2004). While this relationship could indicate more responsibilities for the CEO, it is more often considered to increase the CEO's power and influence over the board, thus reducing its monitoring capabilities. We also include the age of CEOs to represent the experience and, possibly, influence of the CEO on the board. Prior studies also indicate that as boards grow larger, they become less effective at monitoring (Jensen, 1993) and CEO compensation may be larger and/or less sensitive to performance. Although prior research generally supports this assumption (Core et al., 1999; Fahlenbrach, 2009), Grinstein and Hribar (2004) find the opposite. Therefore, the relationship between board size and CEO compensation may not be linear, or may be affected by other factors.

We expect outside, independent directors to be more objective and to better serve shareholders. The compensation committee is charged with determining CEO compensation, which is then approved by the board. Post-SOX, a majority of board directors are required to be outside, independent directors and all compensation committee members are required to be outside, independent directors. We measure the independence of the total board of directors by calculating the number of outside directors divided by the total number of directors on the board. Regarding compensation committee independence, prior research indicates that this attribute has little influence on CEO compensation and that most companies already were in compliance with outside directors on the compensation committee pre-SOX (Andersen and Bizjak, 2003; Petra and Dorata, 2008). We expect little pre-SOX variation in this attribute and no post-SOX variation. Therefore, we do not include a measure of compensation committee independence in our study. However, we do expect that compensation committees that are more representative of independent directors on the full board, and those that are more diligent, will be more effective in their monitoring. We expect larger compensation committees (relative to total board size) and compensation committees that meet more often (relative to the number of total board meetings) to be associated with smaller CEO compensation.

We analyze the relationship between CEO compensation and performance using a logarithmic transformation of the general model in order to reduce the problem of heteroscedasticity in the error terms. It is expected that that this measure of CEO compensation is influenced by the decisions of the board of directors and the compensation committee. In the next section we describe the data and the research design.

We use a panel data of cross-section-time series in our estimation model, as shown below:

$\log \_$PayPerform $_{\text {it }}=\alpha+\beta\left(\log \_S a l e s_{\mathrm{it}}\right)+\gamma\left(\right.$ Ret_3yr $\left._{\mathrm{it}}\right)+\lambda_{1}\left(\mathrm{Age}_{\mathrm{it}}\right)+\lambda_{2}\left(\mathrm{CEO}_{-} \mathrm{Chair}_{\mathrm{it}}\right)+\lambda_{3}\left(\mathrm{CCMeet}_{-} \mathrm{BdMeet} \mathrm{it}_{\mathrm{t}}\right)+$ $\lambda_{4}($ CCSize_BdSize $i t)+\lambda_{5}($ OutDir_BdSize $)+\lambda_{6}\left(\log _{-} B d\right.$ Size $\left._{i t}\right)+\varepsilon_{i t}+v_{i t}$

\section{SAMPLE SELECTION AND DATA}

This section describes the sample, data sources and variable measurement. All compensation and financial data for this study are drawn from Standard \& Poor's (2007) ExecuComp database covering the period 1999-2005.

We use variable components of the CEO compensation, by subtracting salary and "other compensation" from the total ex-ante compensation, to examine the influence of the economic and governance variables. We calculate the logarithm of this Pay for Performance compensation measure as the dependent variable (Log_PayPerform) for our model.

We use sales as proxy for size and complexity. We also use logarithm of sales (Log_Sales) as the proxy for the firm's size and complexity. Our regression model incorporates a market based measure of performance. To measure firm performance, we include the three-year total return as the measure of firm performance in our model. We use three-year total return to shareholders, including the monthly reinvestment of dividends, (Ret_3yr), including the monthly reinvestment of dividends.

Additional governance data are collected from annual proxy statements (Form DEF14A) as filed with the SEC though the EDGAR archives. They are: (a) the number of directors on the board; (b) the number of the 
compensation committee members; (c) the number of annual meetings of the board of directors; (d) the number of annual meetings of the compensation committee; and (e) CEO duality.

We expand the compensation model (2) to include several governance variables including CEO age, a binary dummy variable to control for CEO duality (CEO_Chair), and use the logarithm of number of directors (Log_BdSize) to measure the effect of the size of the board on CEO compensation. Three ratios, the number of outside directors in relation to the board size (OutDir_BdSize), compensation committee size relative to the size of the board of directors (CCSize_BdSize), and the compensation committee meetings relative to the number of board meetings (CCMeet_BdMeet), are calculated as indicators for the independence of the board and the compensation committee influence and diligence. These variables are defined in Appendix 1.

\section{Sample Selection and Descriptive Statistics}

This sample is obtained from an initial sample of 2,398 U.S. firms after imposing the condition that data extend over the entire period 1999 to 2005 . This condition is imposed to guarantee homogeneity in the payperformance relationship and to control to some degree for human capital heterogeneity within firms before and after the enactment of SOX in 2002. The sample was reduced to 318 firms and 2,226 firm-years, referred to as the "Full Sample." Table 1 presents the summary of the sample selection process.

Table 1

Sample Selection

\begin{tabular}{|l|c|c|}
\hline & Number of Firms & CEO-Year \\
\hline Initial Sample & 2,398 & 16,729 \\
\hline Less: Missing annual data during 1999-2005 & 2,043 & 14,244 \\
\hline Less: Missing data/ variables & 37 & 259 \\
\hline Full Sample & $\mathbf{3 1 8}$ & $\mathbf{2 , 2 2 6}$ \\
\hline
\end{tabular}

Detailed information about industry composition of the sample is presented in Table 2 . The sample encompasses 25 industries, with 2-digit SIC ranging from 01 to 99 . The largest sample representation is the Industrial Machines and Equipment, with 36 firms or about 11.3 percent of the sample, followed by Chemical Manufacturing with 31 firms (9.7 percent), Electrical Equipment 28 firms (8.8 percent), Banks and Savings and Loans 27 firms (8.5 percent), Insurance and Other Financials 24 firms (7.5 percent), Service 20 firms (6.3 percent), etc.

Financial statement data such as sales, total assets, ROA, ROE, total return to shareholders (RET) are obtained from ЕхесиСотр Database. Descriptive statistics are reported in Table 3. Panel A displays certain firm characteristics for the sample. The average firm in the sample has $\$ 7,217.081$ million in sales and $\$ 14,890.94$ million in total assets. The average market capitalization is $\$ 10,916.99$ million. The average firm is profitable as indicated by the average ROA, ROE and RET. Panel B displays three measures of total compensation. These measures are obtained from the ExecuComp Database. The ex-ante average CEO total compensation (TDC1) is $\$ 5,776.534$ thousand while the amounts in 1999 and 2005 were $\$ 4,257.207$ thousand and $\$ 7,021.656$ thousand, respectively. Panel $\mathrm{C}$ displays certain governance characteristics. There are on average 10 directors sitting on the Board and in $70.53 \%$ of the firms the CEO is also the Chairman. 
Table 2

Industry Composition

\begin{tabular}{|c|c|c|c|}
\hline \multirow{3}{*}{ Industries } & \multirow{3}{*}{ 2-digit SIC } & \multirow{2}{*}{\multicolumn{2}{|c|}{ Full Sample }} \\
\hline & & & \\
\hline & & Number of Obs. & $\%$ \\
\hline Apparel & 56 & 28 & 1.3 \\
\hline Chemical Manufacturing & 28 & 217 & 9.7 \\
\hline Communication & 48 & 28 & 1.3 \\
\hline Construction/Contracting & $15,16,17$ & 49 & 2.2 \\
\hline Drugs \& Pharmaceuticals & 59 & 35 & 1.6 \\
\hline Electrical Equip & 36, & 196 & 8.8 \\
\hline Entertainment \& Leisure & 39,79 & 42 & 1.9 \\
\hline Food and Beverages & $20,54,58$ & 112 & 5.0 \\
\hline Household Furniture & 57 & 14 & 0.6 \\
\hline Industrial Machines \& Equip & 35,38 & 252 & 11.3 \\
\hline Insurance and Other Financials & $61,62,63,64,67$ & 168 & 7.5 \\
\hline Lumbers \& Mills & 24, & 21 & 0.9 \\
\hline Merchandise & 53, & 42 & 1.9 \\
\hline Metals & 33,34 & 42 & 1.9 \\
\hline Manufacturing & $22,23,25,30,31,32$ & 98 & 4.4 \\
\hline Mineral Resources & 14 & 21 & 0.9 \\
\hline Oil \& gas & 13,29 & 77 & 3.5 \\
\hline Paper Mills Prod & 26 & 56 & 2.5 \\
\hline Print Publications & 27, & 35 & 1.6 \\
\hline S\&L and Banks & 60 & 189 & 8.5 \\
\hline Services & $72,73,80,82,87$ & 140 & 6.3 \\
\hline Transportation Equip & 37 & 133 & 6.0 \\
\hline Transportation & $40,42,44,45,55$ & 63 & 2.8 \\
\hline Utilities & 49 & 91 & 4.1 \\
\hline Wholesale & 50,51 & 77 & 3.0 \\
\hline TOTAL & & 2226 & 100 \\
\hline
\end{tabular}

Table 3

Descriptive Statistics

\begin{tabular}{|c|c|c|c|c|c|}
\hline & & & & & \\
\hline Dorata & & Mean & & MIIn & Max \\
\hline \multicolumn{6}{|l|}{ Panel A } \\
\hline Sales & 2226 & 7217.081 & 20320.51 & 2.361 & 313335 \\
\hline Total Assets & 2226 & 14890.94 & 42654.29 & 28.312 & 520755 \\
\hline Market Cap. & 2226 & 10916.99 & 26594.69 & 19.049 & 275006 \\
\hline ROA & 2226 & 4.320627 & 13.87661 & -388.316 & 59.59 \\
\hline ROE & 2198 & 12.10903 & 43.03004 & -740.231 & 1274.138 \\
\hline RET_3yr & 2214 & 13.18836 & 25.49751 & -74.839 & 280.032 \\
\hline \multicolumn{6}{|l|}{ Panel B } \\
\hline Total compensation (Ex-ante) & 2225 & 5776.534 & 7086.137 & 284.595 & 106841 \\
\hline CEO Incentive Compensation (Pay_Perform) & 2225 & 4930.353 & 6737.83 & 31.235 & 106365.9 \\
\hline Cash Bonus & 2226 & 959.4761 & 1769.018 & 0 & 30402.45 \\
\hline \multicolumn{6}{|l|}{ Panel C } \\
\hline Age & 2223 & 52.9 & 6.66 & 32 & 78 \\
\hline CEO Duality & 2226 & .705301 & .4560098 & 0 & 1 \\
\hline Board Size & 2226 & 9.961815 & 2.922963 & 4 & 25 \\
\hline No. of Outside Directors & 2226 & 7.614106 & 2.700605 & 2 & 22 \\
\hline Compensation Committee Size & 2226 & 3.857143 & 1.28055 & 2 & 12 \\
\hline No. of Board Meetings & 2225 & 6.93618 & 2.767597 & 3 & 32 \\
\hline No. of Comp. Comm. Meetings & 2211 & 4.159656 & 2.058273 & 0 & 17 \\
\hline
\end{tabular}


The sample was partitioned into two time periods, "Before" and "After" SOX, 1999-2002 and 2003-2005, respectively. We also partitioned the sample based on average sales for each panel into "Lower Half" and "Upper Half" in order to extract the effect of SOX on companies based on company average sales over 1999-2005 as shown in Figure 1.

Figure 1

Total Sample of 318 Companies

\begin{tabular}{|l|l|l|}
\hline \begin{tabular}{|l|l|} 
ITime Period \\
Company Size \} & $\begin{array}{l}\text { Before SOX } \\
(1)\end{array}$ & $\begin{array}{l}\text { After SOX } \\
(2)\end{array}$ \\
\hline Lower half : based on Average Panel Sales (3) & $\begin{array}{l}\text { Small Firms } \\
(159 \text { Cos. })\end{array}$ & $\begin{array}{l}\text { Small Firms } \\
(159 \text { Cos. })\end{array}$ \\
\hline Upper half : based on Average Panel Sales (4) & $\begin{array}{l}\text { Large Firms } \\
(159 \text { Cos. })\end{array}$ & $\begin{array}{l}\text { Large firms } \\
(159 \text { Cos. })\end{array}$ \\
\hline
\end{tabular}
\end{tabular}

We will examine the relationship between CEO incentive pay and economic and governance variables over the full period of 1999-2005 as well as the two sub-periods, pre- and post-SOX. We will also estimate the parameters of the model for the lower half of the firms and upper half of the firms in our sample, as measured by the average sales over the seven-year period (1999-2005), to refine our estimation process. We will then compare estimated parameters for the sub periods and upper and lower half of the sample to determine any statistical differences over time and across upper and lower half of the sample.

The sample contains data from a wide variety of firms: those in the Standard \& Poor's 500, Standard and Poor's Mid-Cap 400, and Standard and Poor's Small-Cap 600, which provide considerable variation in firm size. ${ }^{3}$ As noted, the sample period covers a four-year period prior to, and three-year period after, the enactment of SOX.

We use the incentive components of total executive compensation as we deduct total salary and Other Annual compensations from the ex-ante total compensation, i.e., the TDC1 variable in ExecuComp data. TDC1 is total compensation comprised of the following: Salary, Bonus, Other Annual, Total Value of Restricted Stock Granted, Total Value of Stock Options Granted, Long-Term Incentive Payouts, Stock options are valued at the grant-date using ExecuComp's modified Black and Scholes (1973) methodology. ${ }^{4}$

We use random effect regression to analyze the impact of economic and governance variables on the CEO compensation measure, using a cross-section, time-series panel data that includes seven observations for each firm for the years 1999 to 2005. Panel data have become increasingly relevant in applied research (Hsiao, 2003; Baltagi, 2001; Wooldridge, 2002). The panel data analyses employed in this study utilizes spatial and temporal dimensions of the balanced panels to capture the relationship of economic and governance structure of the sample companies in explaining variations in CEO incentive-based compensation.

The spatial dimension pertains to the set of cross-sectional units of observations. The temporal dimension pertains to periodic observations of a set of variables characterizing these cross-sectional units over a particular time span. The advantage of pooled estimators over heterogeneous estimators is that individual regressions often yield unreliable and implausible coefficients.

If there are $\mathrm{N}$ units of observations and if the study is undertaken $\mathrm{T}$ time periods, there are potentially NT observations consisting of time series of length $\mathrm{T}$ on $\mathrm{N}$ parallel units. This results in more efficient estimates. Furthermore, the use of panel data offers a solution to the problem of bias caused by unobserved heterogeneity. Unobserved heterogeneity refers to unobserved qualities present in the unit under consideration but unknown to the

\footnotetext{
${ }^{3}$ The sample consists of 142 S \& P 500 firms, 78 Mid-Cap, and 68 Small-Cap firms. Thirty firms did not have S \& P classification.

${ }^{4}$ ExecuComp's modified Black-Scholes formula - ExecComp values options using an "expected life" equal to $70 \%$ of the actual term. In addition, ExecComp sets volatilities below the 5th percentile or above the 95th percentile to the 5th and 95th percentile volatilities, respectively; similarly, dividend yields above the 95th percentile are reduced to the 95th percentile.
} 
researcher. For example, it is rather obvious that all CEO contracts are not the same. Each company has certain traits, qualities, characteristics, etc., that are difficult to quantify. In cross-section analysis, unobserved heterogeneity is captured by the error term. However, the central assumption of regression theory is that the explanatory variable and the error term are uncorrelated, i.e., that the explanatory variable is exogenous. As unobserved heterogeneity is captured by the error term, this assumption is violated. With panel data, instead, it is possible to correctly identify the true effects, even in the presence of unobserved heterogeneity (Baltagi, 2001).

In the panel data estimation one may choose between the random effect and fixed effect models. According to Judge et al. (1988) the difference in results is rather small for a large $\mathrm{T}$ and a small $\mathrm{N}$. In the case of a small $\mathrm{T}$ relative to $\mathrm{N}$ the fixed effect model is inefficient though consistent and, as such, a random effect model may be preferred. For relatively smaller $\mathrm{T}$ the worst in applying the fixed effect model is its inefficiency.

Our methodology enhances analysis of CEO compensation by including periodic observations of a set of variables characterizing these cross-sectional units over a particular time span. As such, panel data analyses are more informative, display a higher degree of variability, suffer less from problems of multicollinearity, and have more degrees of freedom.

\section{ANALYSES AND RESULTS}

We present the results of our estimations in three sections. First the results for the full period and pre- and post-SOX periods will be presented. Then, we partition the sample based on firm size and will repeat our estimations. Finally, we will compare the estimated parameters for sub-samples to discern incremental affect of variables over sub-samples.

Generally, our results indicate a significant positive influence of Log_Sales and Ret_3yr on the CEO compensation, at the 1 percent significance level in all estimations except for the results for the smaller firms during the post-SOX period when the return variable is not as significant (at the .10 level). Consistent with prior studies, these economic variables appear to significantly and positively affect the incentive compensation of the CEOs.

Furthermore, Age of CEO positively affects CEO compensation for larger firms in the upper half of the sample. This finding seems plausible since CEO's experience can be a major factor in more established firms. The number of directors, in general, negatively affect the incentive compensation for CEOs in our full sample and preSOX estimations and appears to be significant for smaller firms in both pre and post-SOX results, while the coefficient is positive and marginally significant for larger firms during the post-SOX period. The ratio of outside directors to the number of board members appears to have a positive and significant effect on CEO incentive pay, mainly for smaller firms during the pre-SOX period. The effects of all other governance variables are generally negative but not statistically significant at any conventional level except for the CEO duality, in the full sample estimations, and to a lesser degree during the pre-SOX period, which is significant at the 5 percent level. These findings are described in more detail in the next section.

\section{The Full period and Pre- and Post-SOX Results}

The results of our estimations, using Pay_Perform as the dependent variables, are reported in Table 4. As indicated above, sales and returns variable are positive and statistically significant variables, at the .01 level, for the full period as well as the pre- and post-SOX periods. CEO's age variable also appears to have a positive and statistically significant influences on CEO incentive pay, albeit it is marginally significant, at the .10 level, during the post-SOX period. The percentage of outside directors on the board (OutDir_BdSize) positively and significantly affects the CEO's incentive pay. This result appears to be driven by the pre-SOX data since the variable does not have a significant influence on pay post-SOX.

The size of the board of directors and the CEO duality variables have a negative and significant impact, at the .05 level, on incentive pay over the full period and during the pre-SOX period. These are in the unexpected direction as compared with findings in prior studies. Other governance variables, CCmeet_BdMeet and CCSize_BdSize, have negative coefficient in all three estimations, but are not statistically significant at any conventional level. 
The overall R-Squared for the full period, pre- and post-SOX, as shown in Table 4, is $0.37,0.32$, and 0.45 , respectively. The joint test of null hypotheses of coefficients of the models equal to zero is rejected for the full period, pre- and post-SOX models, as indicated by the Wald $\chi^{2}$ at any significance level.

Table 4

Cross-Section, Time-Series Regression-Random Effect

Dependent Variable: Log Pay_Perform

\begin{tabular}{|c|c|c|c|}
\hline \\
\hline Variables & $1999-2005$ & $\begin{array}{l}\text { Pre- SOX } \\
1999-2002 \\
\end{array}$ & $\begin{array}{l}\text { Post- SOX } \\
\text { 2003-2005 } \\
\end{array}$ \\
\hline Log_Sales & $\begin{array}{c}0.4872919 * * * \\
(20.02)\end{array}$ & $\begin{array}{c}0.4442107 * * * \\
(14.74) \\
\end{array}$ & $\begin{array}{c}0.4575627 * * * \\
(16.05) \\
\end{array}$ \\
\hline Ret_3yr & $\begin{array}{c}0.6768507 * * * \\
(14.44)\end{array}$ & $\begin{array}{c}0.5263709^{* * *} \\
(8.70) \\
\end{array}$ & $\begin{array}{c}0.5026073 * * * \\
(4.89) \\
\end{array}$ \\
\hline Age & $\begin{array}{c}0.0364553 * * * \\
(8.00)\end{array}$ & $\begin{array}{c}0.0353598 * * * \\
(5.32)\end{array}$ & $\begin{array}{c}0.0104903 * \\
(1.65)\end{array}$ \\
\hline CEO_Chair & $\begin{array}{c}-0.1030312 * * * \\
(-2.70)\end{array}$ & $\begin{array}{c}-0.1356021 * * \\
(-2.52)\end{array}$ & $\begin{array}{c}-0.0349475 \\
(-0.52)\end{array}$ \\
\hline CCMeet_BdMeet & $\begin{array}{c}-0.0711479 \\
(-1.50)\end{array}$ & $\begin{array}{c}-0.0150389 \\
(-0.20)\end{array}$ & $\begin{array}{c}-0.0118234 \\
(-0.19)\end{array}$ \\
\hline CCSize_BdSize & $\begin{array}{c}-0.2743534 \\
(-1.59) \\
\end{array}$ & $\begin{array}{c}-0.3791091 \\
(-1.52)\end{array}$ & $\begin{array}{c}-0.176747 \\
(-0.66)\end{array}$ \\
\hline OutDir_BdSize & $\begin{array}{c}0.3660864 * * \\
(2.01)\end{array}$ & $\begin{array}{c}0.7572595 * * * \\
(3.14) \\
\end{array}$ & $\begin{array}{c}0.0215224 \\
(0.07)\end{array}$ \\
\hline Log_BdSize & $\begin{array}{c}-0.2828075^{* * *} \\
(-2.77)\end{array}$ & $\begin{array}{c}-0.3637396^{* * *} \\
(-2.61) \\
\end{array}$ & $\begin{array}{c}-0.1520373 \\
(-0.97) \\
\end{array}$ \\
\hline Constant & $\begin{array}{c}2.754774 * * * \\
(8.34) \\
\end{array}$ & $\begin{array}{c}3.067581 * * * \\
(6.55) \\
\end{array}$ & $\begin{array}{c}4.286949 * * * \\
(8.89) \\
\end{array}$ \\
\hline \multicolumn{4}{|l|}{ R-Squared: } \\
\hline $\begin{array}{l}\text { Within } \\
\text { between } \\
\text { overall }\end{array}$ & $\begin{array}{l}0.2578 \\
0.4034 \\
0.3690 \\
\end{array}$ & $\begin{array}{l}0.1831 \\
0.3382 \\
0.3162 \\
\end{array}$ & $\begin{array}{l}0.1128 \\
0.4864 \\
0.4467 \\
\end{array}$ \\
\hline Number of Obs. & 2209 & 1255 & 954 \\
\hline Wald $\chi^{2}$ & $\begin{array}{c}850.37 \\
(0.0000) \\
\end{array}$ & $\begin{array}{c}365.57 \\
(0.0000) \\
\end{array}$ & $\begin{array}{c}376.97 \\
(0.0000) \\
\end{array}$ \\
\hline
\end{tabular}

Coefficients Significance Level: ***.01, **.05, *.1

\section{Partitioned Samples Results}

We estimated the parameters of our model by dividing the sample into small and large firms based on the average sales over the 7-year period and repeated our analyses for the pre- and post-SOX periods. These results are presented in Table 5. The Log_Sales continues to be a significant explanatory variable for incentive pay regardless of partitioning at the .01 level. The Ret_3yr also appears to have a significant and positive impact on CEO incentive pay during the pre-SOX period for both small and large firms, at the .01 level. This variable remains highly significant for larger firms during post-SOX period, but is only marginally significant, at the .10 level, during this period for smaller firms.

Among governance variables, Age appears to be significant at .01 level for larger firms during the pre- and post-SOX and the size of the board of directors is negative and significant for smaller firms pre- and post-SOX at .01 and .05 significance levels, respectively, while positive and marginally significant, at .10 level, for large firms only during the post-SOX period.

The overall R-Squared for the pre- and post-SOX periods, as reported in Table 5, is 0.17 and 0.24 for smaller firms and 0.30 and 0.37 for larger firms, respectively. The joint test of null hypotheses of coefficients of the models equal to zero is rejected for the all estimation models as indicated by the Wald $\chi^{2}$ at any significance level. 
Table 5

Cross-Section, Time-Series Regression-Random Effect Dependent Variable: Log Pay_Perform

\begin{tabular}{|c|c|c|c|c|}
\hline \multirow[t]{2}{*}{ Variables } & \multicolumn{2}{|c|}{$\begin{array}{l}\text { Pre- SOX } \\
\text { 1999-2002 } \\
\end{array}$} & \multicolumn{2}{|c|}{$\begin{array}{l}\text { Post- SOX } \\
\text { 2003-2005 }\end{array}$} \\
\hline & Small Firms & Large Firms & Small Firms & Large Firms \\
\hline Log_Sales & $\begin{array}{c}0.4684534 * * * \\
(8.23)\end{array}$ & $\begin{array}{c}0.5322644 * * * \\
(9.17)\end{array}$ & $\begin{array}{c}0.4845897 \text { *** } \\
(7.88)\end{array}$ & $\begin{array}{c}0.5107625 \text { *** } \\
(9.56)\end{array}$ \\
\hline Ret_3yr & $\begin{array}{c}0.5708585^{* * * *} \\
(7.79)\end{array}$ & $\begin{array}{c}0.361328 * * * \\
(3.10)\end{array}$ & $\begin{array}{c}0.2667519 * \\
(1.83)\end{array}$ & $\begin{array}{c}0.8930323 * * * \\
(6.00)\end{array}$ \\
\hline Age & $\begin{array}{c}0.0105891 \\
(1.16)\end{array}$ & $\begin{array}{c}0.0627407 * * * \\
(6.73)\end{array}$ & $\begin{array}{c}-0.0045821 \\
(-0.51)\end{array}$ & $\begin{array}{c}0.0298475^{* * * *} \\
(3.50)\end{array}$ \\
\hline CEO_Chair & $\begin{array}{c}-0.1371703 \\
(-1.65)\end{array}$ & $\begin{array}{c}-0.1170197 * \\
(-1.70)\end{array}$ & $\begin{array}{c}-0.052036 \\
(-0.53)\end{array}$ & $\begin{array}{c}0.0303966 \\
(0.35)\end{array}$ \\
\hline CCMeet_BdMeet & $\begin{array}{c}-0.0735929 \\
(-0.63)\end{array}$ & $\begin{array}{c}0.0314679 \\
(0.32)\end{array}$ & $\begin{array}{c}0.0537348 \\
(0.58)\end{array}$ & $\begin{array}{c}-0.103097 \\
(-1.26)\end{array}$ \\
\hline CCSize_BdSize & $\begin{array}{c}-0.6351393 \\
(-1.70)\end{array}$ & $\begin{array}{c}-0.17793 \\
(-0.54)\end{array}$ & $\begin{array}{c}-0.5768886 \\
(-1.47)\end{array}$ & $\begin{array}{c}0.3827898 \\
(1.09)\end{array}$ \\
\hline OutDir_BdSize & $\begin{array}{c}1.067585^{* * * *} \\
(2.91)\end{array}$ & $\begin{array}{c}0.4328401 \\
(1.37)\end{array}$ & $\begin{array}{c}0.342028 \\
(0.73)\end{array}$ & $\begin{array}{c}-0.4074877 \\
(-1.18)\end{array}$ \\
\hline Log_BdSize & $\begin{array}{c}-0.6609829 * * * \\
(-3.22)\end{array}$ & $\begin{array}{c}-0.0498016 \\
(-0.27)\end{array}$ & $\begin{array}{c}-0.5298433 * * \\
(-2.29)\end{array}$ & $\begin{array}{c}0.4111757 * * \\
(2.03)\end{array}$ \\
\hline Constant & $\begin{array}{c}4.770431 * * * * \\
(6.96)\end{array}$ & $\begin{array}{c}0.2035336 \\
(0.27)\end{array}$ & $\begin{array}{c}5.681368^{* * * *} \\
(7.98)\end{array}$ & $\begin{array}{c}1.460071 * \\
(1.92)\end{array}$ \\
\hline \multicolumn{5}{|l|}{ R-Squared: } \\
\hline $\begin{array}{l}\text { Within } \\
\text { between } \\
\text { overall }\end{array}$ & $\begin{array}{l}0.2082 \\
0.1613 \\
0.1709\end{array}$ & $\begin{array}{l}0.1588 \\
0.3330 \\
0.3045\end{array}$ & $\begin{array}{l}0.0684 \\
0.2683 \\
0.2362\end{array}$ & $\begin{array}{l}0.2274 \\
0.3872 \\
0.3679\end{array}$ \\
\hline Number of Obs. & 623 & 632 & 477 & 477 \\
\hline Wald $\chi^{2}$ & $\begin{array}{c}148.72 \\
(0.0000)\end{array}$ & $\begin{array}{c}165.06 \\
(0.0000)\end{array}$ & $\begin{array}{c}80.47 \\
(0.0000)\end{array}$ & $\begin{array}{c}190.06 \\
(0.0000)\end{array}$ \\
\hline
\end{tabular}

Coefficients Significance Level: ***.01,**.05,*.1

\section{Testing Differences between Sub-Samples}

We also examined the difference in estimated coefficients by comparing the coefficient for partitioned samples. For example, the estimation models for pre-SOX period, model 4, and post-SOX period, model 5, are specified as follows:

Pre-SOX: $\quad$ Log_PayPerform it $=\alpha+\beta\left(\log \_S a l e s_{i t}\right)+\gamma\left(\operatorname{Ret}_{-} 3 \mathrm{yr}_{\mathrm{it}}\right)+\lambda_{1}\left(\mathrm{Age}_{\mathrm{it}}\right)+\lambda_{2}\left(\mathrm{CEO} \_\mathrm{Chair} \mathrm{it}_{\mathrm{it}}\right)+$ $\lambda_{3}($ CCMeet_BdMeet $i t)+\lambda_{4}\left(\right.$ CCSize_BdSize $\left.{ }_{i t}\right)+\lambda_{5}($ OutDir_BdSize $)+\lambda_{6}\left(\right.$ Log_BdSize $\left._{i t}\right)+\varepsilon_{i t}+v_{\text {it }}$

Post-SOX: Log_PayPerform it $=\alpha^{\prime}+\beta^{\prime}\left(\log \_S a l e s_{i t}\right)+\gamma^{\prime}\left(\operatorname{Ret}_{-} 3 \mathrm{yr}_{\mathrm{it}}\right)+\lambda_{1}{ }^{\prime}\left(\mathrm{Age}_{\mathrm{it}}\right)+\lambda_{2}{ }^{\prime}\left(\mathrm{CEO}_{-} \mathrm{Chair}\right.$ it $)+$ $\lambda_{3}{ }^{\prime}\left(\right.$ CCMeet_BdMeet $\left._{i t}\right)+\lambda_{4}{ }^{\prime}\left(\right.$ CCSize_BdSize $\left._{\mathrm{it}}\right)+\lambda_{5}{ }^{\prime}\left(\mathrm{OutDir}_{-}\right.$BdSize $)+\lambda_{6}{ }^{\prime}\left(\log _{-}\right.$BdSize $\left._{i t}\right)+\varepsilon_{i t}+v_{\text {it }}$

Then, we test the following null hypotheses jointly and individually using Wald $\chi^{2}$ :

$\beta-\beta^{\prime}=0$,

$\gamma-\gamma^{\prime}=0$

$\lambda_{1}-\lambda_{1}{ }^{\prime}=0$,

$\lambda_{2}-\lambda_{2}^{\prime}=0$,

$\lambda_{3}-\lambda_{3},=0$

$\lambda_{4}-\lambda_{4}{ }^{\prime}=0$,

$\lambda_{5}-\lambda_{5}{ }^{\prime}=0$

$\lambda_{6}-\lambda_{6}{ }^{\prime}=0$ 
Where, in this example, $\beta, \gamma, \lambda_{1}, \lambda_{2}, \lambda_{3}, \lambda_{4}, \lambda_{5}, \lambda_{6}$, and $\beta^{\prime}, \gamma^{\prime}, \lambda_{1}{ }^{\prime}, \lambda_{2}{ }^{\prime}, \lambda_{3}{ }^{\prime}, \lambda_{4}{ }^{\prime}, \lambda_{5}{ }^{\prime}, \lambda_{6}{ }^{\prime}$ are the two sets of estimated parameters for pre and post-SOX models.

We first examined the pre/post-SOX estimated coefficients as shown in Table 6. The tests of null hypotheses of no difference for all parameters in the model jointly as well as the joint test of governance variables' parameters are rejected. We also examined the null hypothesis of no difference for each pair of parameters. The null hypotheses for Ret_3yr and Log_BdSize are rejected. It appears that firms are even more likely post-SOX to focus on returns. However, larger boards are more likely to approve higher pay post-SOX. The null hypothesis for all other tests cannot be rejected at any conventional level.

Table 6

Wald Parameter Tests*

$\chi^{2}$ for testing difference between the coefficients

\begin{tabular}{|l|c|}
\hline \multicolumn{1}{|c|}{ Variables } & $\varphi_{(\text {pre-SOX) }}-\varphi^{\prime}{ }_{(\text {post-Sox })}$ \\
\hline Log_Sales & 1.23 \\
& $(0.2669)$ \\
\hline Ret_3yr & $20.80^{* *}$ \\
& $(0.0000)$ \\
\hline Age & 1.30 \\
& $(0.2537)$ \\
\hline CEO_Chair & 0.60 \\
& $(0.4402)$ \\
\hline CCMeet_BdMeet & 0.19 \\
& $(0.6662)$ \\
\hline CCSize_BdSize & 1.97 \\
& $(0.1602)$ \\
\hline OutDir_BdSize & 1.13 \\
& $(0.2868)$ \\
\hline Log_BdSize & $10.12^{* *}$ \\
& $(0.0015)$ \\
\hline All Parameters & $45.49^{* *}$ \\
& $(0.0000)$ \\
\hline Wald Joint Test of Governance Variables: & $13.08^{* *}$ \\
& $(0.0418)$ \\
\hline Age & \\
\hline CEO_Chair & \\
\hline CCMeet_BdMeet & \\
\hline CCSize_BdSize & \\
\hline OutDir_BdSize & \\
\hline Log_BdSize & \\
\hline$* \chi^{2}$ for testing equality of the coefficients in the sub samples where $\chi^{2}$ Prob. values are shown parenthetically. \\
$* *$ cannot Accept $\varphi-\varphi^{\prime}=0$, where $\varphi$ and $\varphi^{\prime}$ represents the coefficient of variables for Pre and Post-SOX, at .05 significance \\
level. Otherwise, the hypothesis of no difference cannot be rejected at .05 level. \\
\hline
\end{tabular}

We then examined the null hypothesis of no difference comparing small or large firms for pre-SOX and Post-SOX periods (SOX effect), as shown in Table 7. The joint test of no difference for all parameters in the model is rejected for both small and large groups at the .01 level while the joint test of governance variables' parameters is rejected for only the pre-SOX period. The test of null for individual variables, comparing small and large firms, is rejected in the case of Log_Sales (small and large firms) during the pre-SOX and the post-SOX periods, Ret_3yr (post-SOX period), CEO age (pre-SOX period), and board size (pre-SOX period). The null cannot be rejected for any other case during either period.

We also compared the parameters small and large firms (Size Effect) during the pre-SOX period and repeated this comparison for the post-SOX period. The joint test of no difference for all parameters in the model is rejected for both small and large firms, at the .01 level. We cannot reject joint test of governance variables' 
parameters for either group at the .05 level. The test of null for individual parameters is rejected in the case of Log_Sales (small firms), Ret_3yr and CEO age (large firms), and Board Size (small firms). The null cannot be rejected for any other case in either group.

Table 7

Wald Parameter Tests*

$\chi^{2}$ for testing difference between the coefficients

\begin{tabular}{|c|c|c|c|c|}
\hline \multirow[b]{2}{*}{ Variables } & \multicolumn{2}{|c|}{ SOX Effect } & \multicolumn{2}{|c|}{ Size Effect } \\
\hline & $\begin{array}{c}\text { Pre-SOX } \\
\varphi_{\text {Small Firms }}- \\
\varphi_{\text {Large Firms }}\end{array}$ & $\begin{array}{c}\text { Post-SOX } \\
\varphi_{\text {Small Firms }}- \\
\varphi_{\text {Large Firms }}^{\prime}\end{array}$ & $\begin{array}{c}\text { Small Firms } \\
\varphi_{\text {pre-Sox }}- \\
\varphi_{\text {post-Sox }}^{\prime}\end{array}$ & $\begin{array}{c}\text { Large Firms } \\
\varphi_{\text {pre-Sox }}- \\
\varphi_{\text {post-Sox }}^{\prime}\end{array}$ \\
\hline Log_Sales & $\begin{array}{c}4.74 * * \\
(0.0296)\end{array}$ & $\begin{array}{c}8.76^{* *} \\
(0.0031)\end{array}$ & $\begin{array}{c}4.78^{* *} \\
(0.0289)\end{array}$ & $\begin{array}{c}1.05 \\
(0.3057)\end{array}$ \\
\hline Ret_3yr & $\begin{array}{c}0.03 \\
(0.8627) \\
\end{array}$ & $\begin{array}{l}11.50 * * \\
(0.0007) \\
\end{array}$ & $\begin{array}{c}2.08 \\
(0.1492) \\
\end{array}$ & $\begin{array}{l}15.57 * * \\
(0.0001) \\
\end{array}$ \\
\hline Age & $\begin{array}{c}5.06 * * \\
(0.0244) \\
\end{array}$ & $\begin{array}{c}0.20 \\
(0.66525) \\
\end{array}$ & $\begin{array}{c}0.18 \\
(0.6683)\end{array}$ & $\begin{array}{c}6.19 * * \\
(0.0129)\end{array}$ \\
\hline CEO_Chair & $\begin{array}{c}0.19 \\
(0.6616)\end{array}$ & $\begin{array}{c}0.44 \\
(0.5084)\end{array}$ & $\begin{array}{c}2.02 \\
(0.1554)\end{array}$ & $\begin{array}{c}0.20 \\
(0.6545)\end{array}$ \\
\hline CCMeet_BdMeet & $\begin{array}{c}0.70 \\
(0.4019) \\
\end{array}$ & $\begin{array}{c}0.07 \\
(0.7940) \\
\end{array}$ & $\begin{array}{c}0.72 \\
(0.3970) \\
\end{array}$ & $\begin{array}{c}0.03 \\
(0.8717) \\
\end{array}$ \\
\hline CCSize_BdSize & $\begin{array}{c}0.00 \\
(0.9983) \\
\end{array}$ & $\begin{array}{c}0.42 \\
(0.5145) \\
\end{array}$ & $\begin{array}{c}0.35 \\
(0.5548) \\
\end{array}$ & $\begin{array}{c}1.30 \\
(0.2548) \\
\end{array}$ \\
\hline OutDir_BdSize & $\begin{array}{c}0.11 \\
(0.7390) \\
\end{array}$ & $\begin{array}{c}0.19 \\
(0.6649) \\
\end{array}$ & $\begin{array}{c}0.22 \\
(0.6380) \\
\end{array}$ & $\begin{array}{c}0.92 \\
(0.3362) \\
\end{array}$ \\
\hline Log_BdSize & $\begin{array}{c}8.72 * * \\
(0.0031)\end{array}$ & $\begin{array}{c}0.09 \\
(0.7623)\end{array}$ & $\begin{array}{c}6.43 * * \\
(0.0112)\end{array}$ & $\begin{array}{c}2.76 \\
(0.0968) \\
\end{array}$ \\
\hline All Parameters & $\begin{array}{l}39.73 * * \\
(0.0000) \\
\end{array}$ & $\begin{array}{l}22.49 * * \\
(0.0075) \\
\end{array}$ & $\begin{array}{l}23.13 * * \\
(0.0041) \\
\end{array}$ & $\begin{array}{l}24.71 * * \\
(0.0033) \\
\end{array}$ \\
\hline $\begin{array}{l}\text { Wald Joint Test of } \\
\text { Governance Variables: }\end{array}$ & $\begin{array}{l}17.98 * * \\
(0.0063) \\
\end{array}$ & $\begin{array}{c}1.74 \\
(0.9423) \\
\end{array}$ & $\begin{array}{c}9.97 \\
(0.1258) \\
\end{array}$ & $\begin{array}{c}8.88 \\
(0.1802) \\
\end{array}$ \\
\hline Age & & & & \\
\hline CEO_Chair & & & & \\
\hline CCMeet_BdMeet & & & & \\
\hline CCSize_BdSize & & & & \\
\hline OutDir_BdSize & & & & \\
\hline Log_BdSize & & & & \\
\hline
\end{tabular}

\section{Robustness Test}

This study follows Chhaochharia and Grinstein (2009) in treating 2003 as the first year of the post-SOX period. The year 2002, the year in which SOX was passed, could be considered a transition year rather than truly pre-SOX. To test the impact of 2002, we re-estimated the pre-SOX parameters after dropping the 2002 observations. The results for the full sample and pre-SOX periods were substantially the same as those reported in the analysis section with a few exceptions. The variable OutDir_BdSize is not significant for the full sample and significant only at the 5 percent level during the pre-SOX period. This variable is also less significant, at the 5 percent level, for the smaller firms during the pre-SOX period compared to our original analysis. The incentive compensation appears to be more sensitive to changes Ret_3yr variable for larger firms, during pre-SOX period, while the coefficient is less significant, at 5 percent, than our earlier estimate. 


\section{SUMMARY AND CONCLUSION}

The results of this study indicate that economic determinants and a CEO's age are generally more important than the structure of corporate boards of directors in establishing CEO incentive compensation for CEOs who have a relatively long standing with their companies. This finding seems plausible because a CEO's experience can be a major factor in more established, larger firms.

We also examine the effects of corporate governance on CEO compensation in light of corporate regulatory controls introduced after 2002 by the SOX. Although other studies have examined various aspects of changes in CEO compensation pre- and post-SOX, we also inspect the change in coefficients for economic and governance factors to determine the influence of SOX. Our results suggest that corporate governance variables are not significant post-SOX. In addition to looking at our full sample for the entire period and pre- and post-SOX, we also stratify our sample into two groups by size (sales). We find that there are different patterns and significant influences when comparing large and small firms in our sample. In particular, the pre-SOX negative impact of CEO duality appears to be driven by larger firms while the unexpected signs of some corporate governance variables appear to be associated with smaller firms.

CEO duality was unexpectedly negatively associated with pay, but only during the pre-SOX period. Similarly, in unexpected direction, the percentage of outside directors on the board has a positive and significant effect on the incentive compensation in the full period and during the pre-SOX period. However, as shown in our partitioned sample, it appears that the influence of this variable is mainly due to smaller firms and during the preSOX period.

We also observe that larger boards tended to limit pay in the full and pre-SOX periods. Further partitioning of our data revealed that this effect also is due to smaller firms during the pre-SOX period. Additionally, we observe significantly negative and significantly positive impact of the board size on the compensation for smaller and larger firms, respectively, during the post-SOX period. This latter result may explain the fact that the board size did not appear to be significant during post-SOX period, as reported in Table 5. That is, the opposite and significant impact of board size on smaller and larger firms could be masked in the aggregate analysis.

It may be the case that smaller companies have not developed governance mechanisms as sophisticated as those of larger companies, due to resource constraints or other factors. These results could also be consistent with the substitution hypothesis, where firms with weaker governance mechanisms rely more heavily on performance pay to align the interests of shareholders and management (see, e.g., Fahlenbrach, 2009). Our results indicate that CEO incentive pay in smaller companies was not only significantly associated with the coefficient for sales pre- and postSOX, but it was even more pronounced in both periods than larger firms, and increasingly significant for smaller firms as a reaction to SOX (see results in Table 7).

The use of cross-section, time series panel data, together with partitioning of the data based on the firms' size, provides a unique focus on incorporating the inherent information for the same firms and CEOs over the full period 1999-2005, and the influence of SOX on those firms. Most prior studies use OLS cross-section methodology. Some of our findings may be determined, in part, by focusing on firms with the same CEO over time.

The panel data design of this study introduces the risk of "CEO survivorship bias" in our study. However, we believe this design controls the variability that might otherwise be present, due to either the contracting or the individual qualifications of the CEO, and the tradeoff seems justified. This is a possible limitation of the study in that our results may not be generalizable to public companies with CEO changes that may be associated with other changes in, and influences of, corporate governance and board structure. Future research is needed to better understand the dynamics associated with CEOs and boards over time. 


\section{AUTHOR INFORMATION}

Mahmoud M. Nourayi is the Associate Dean of College of Business Administration and Chair of the Accounting Department at Loyola Marymount University. He received his Ph.D., Business Administration, from University of Southern California. Dr. Nourayi is Certified Financial Manager (CFM), Certified Management Accountant (CMA), and Certified Public Accountant (CPA). His experience includes Tax, Financial and Management Advisory services and auditing in both public accounting and government. Professor Nourayi is a member of the American Accounting Association, Institute of Management Accountants, and the California Society of CPAs. He has been a member of several committees of California Society of CPAs'. He is also a past president of the South Bay Chapter of Institute of Management Accountants. E-mail: Mahmoud.Nourayi@1mu.edu. Corresponding author.

Lawrence Kalbers is the R. Chad Dreier Chair in Accounting Ethics and the director of the Center for Accounting Ethics, Governance, and the Public Interest at Loyola Marymount University. He received his Ph.D. from The Pennsylvania State University and is a Certified Public Accountant. His research interests include corporate governance and internal controls, ethics, professionalism, auditor burnout, auditor organizational commitment, and accounting education. His research has been published in academic and professional journals, including Accounting and Business Research, Advances in Accounting Behavioral Research, Auditing: A Journal of Practice and Theory, Communications of the Association for Information Systems, Critical Perspectives on Accounting, Managerial Auditing Journal, and Review of Accounting and Finance. E-mail: Lawrence.Kalbers@1mu.edu

Frank P. Daroca is Professor of Accounting at Loyola Marymount University in Los Angeles. He holds a Ph.D. from the University of Illinois and is a Certified Public Accountant. Before joining academia, he spent ten years in "Big Four" public accounting and in industry. His research interests include environmental issues, government finance and accounting education. Dr. Daroca has published articles in over a dozen journals. He has taught accounting principles, auditing and managerial accounting at both the graduate and undergraduate level. He is a member of the American Accounting Association. E-mail: Frank.Daroca@lmu.edu

\section{REFERENCES}

1. Agrawal, A., A. Makhija, A. and G. Mandelker. 1991. "Executive Compensation and Corporate Performance in Electric and Gas Utilities", Financial Management 20 (4): 113-124.

2. Andersen, R.C. and J. M. Bizjak. 2003. "An Empirical Examination of the Role of the CEO and the Compensation Committee in Structuring Executive Pay" Journal of Banking and Finance 27 (7): 1323-48.

3. Anderson, M., R. Banker and S. Ravindran. 2000. "Executive Compensation in the Information Technology Industry” Management Science 46 (4): 530-547.

4. Arya, A. and H. L. Sun. 2004. "Impact of Deregulation on CEO Compensation: The Case of Electric Utilities" American Business Review 22 (1): 27-33.

5. Baltagi, B. H. 2001. Econometric Analysis of Panel Data. Chicester, England: John Wiley \& Sons Ltd.

6. Bebchuk, L. A., J. M. Fried and D. I. Walker. 2002. "Managerial Power and Rent Extraction in the Design of Executive Compensation" The University of Chicago Law Review 69 (3): 751-846.

7. Bebchuk, L. A. and J. M. Fried. 2003. "Executive Compensation as an Agency Problem" Journal of Economic Perspectives 17: 71-92.

8. Bebchuk, L. A. and J. M. Fried. 2004. Pay Without Performance: The Unfulfilled Promise of Executive Compensation. Cambridge, MA: Harvard University Press.

9. Bebchuk, L. A., A. Cohen and A. Ferrell. 2009. "What Matters in Corporate Governance?" The Review of Financial Studies 22 (2): 783-827.

10. Berle, A. A. Jr., and G. C. Means. 1932. The Modern Corporation and Private Property. New York, NY: Macmillan Company.

11. Black, F., and M. Scholes. 1973. "The Pricing of Options and Corporate Liabilities" Journal of Political Economy 81: 637-654.

12. Brown, R., N. Gao, E. Lee and K. Stathopoulos. 2009. "What are Friends For? CEO networks, Pay and Corporate Governance" Working paper, Manchester Business School, University of Manchester.

13. Bryan, S., and L. Hwang. 1997. "CEO Compensation in a Regulatory Environment: An Analysis of the Electric Utility Industry” Journal of Accounting, Auditing \& Finance 12 (3): 223-255. 
14. Carter, M. E., L. J. Lynch and S. L. C. Zechman. 2009. "Changes in Bonus Contracts in the Post-SarbanesOxley Era” Review of Accounting Studies 14: 480-506.

15. Chhaochharia, V. and Y. Grinstein. 2009. "CEO compensation and board structure” Journal of Finance 64 (1): 231-261.

16. Cheng, Q. and D. B. Farber. 2008. "Earnings Restatements, Changes in CEO Compensation, and Firm Performance" The Accounting Review 83 (5): 1217-1250.

17. Cohen, D. A., A. Day and T. Z. Lys. 2004. "Trends in Earnings Management and Informativeness of Earnings Announcements in the Pre- and Post-Sarbanes-Oxley Periods" Working Paper, Northwestern University.

18. Cohen, D. A., A. Day and T. Z. Lys. 2009. "The Sarbanes-Oxley Act of 2002: Implications for Compensation Contracts and Managerial Risk-Taking” Working Paper, accessed on July 4, 2011, http://webdocs.stern.nyu.edu/old web/emplibrary/CDL SOX II \%20September 09 2009 FINAL.pdf.

19. Core, J. E., R. W. Holthausen and D. F. Larcker. 1999. "Corporate Governance, Chief Executive Officer Compensation, and Firm Performance” Journal of Financial Economics 51 (3): 371-406.

20. Fahlenbrach, R. 2009. "Shareholder Rights, Boards, and CEO Compensation" Review of Finance 13: 81113.

21. Fama, E. F. 1980. "Agency Problems and the Theory of the Firm” Journal of Political Economics 88: 288307.

22. Fama, E. F. and M. C. Jensen. 1983. "Separation of Ownership and Control” Journal of Law and Economics 26: 301-325.

23. Grinstein, Y. and P. Hribar. 2004. "CEO Compensation and Incentives: Evidence from M\&A Bonuses" Journal of Financial Economics 73: 119-143.

24. Grossman, S. J. and O. D. Hart. 1983. "An Analysis of the Principal-Agency Problem”, Econometrica 53 (1): 7-46.

25. Guay, W. 1999. "The Sensitivity of CEO Wealth to Equity Risk: An Analysis of Magnitude and Determinants" Journal of Financial Economics 53 (1): 43-71.

26. Hsiao, C. 2003. Analysis of Panel Data, 2nd Edition. New York, NY: Cambridge University Press.

27. Jensen, M. C. and W. H. Meckling. 1976. "Theory of the Firm, Managerial Behavior, Agency Costs and Ownership Structure” Journal of Financial Economics 3 (4): 305-360.

28. Jensen, M. C. 1993. "The Modern Industrial Revolution, Exit, and the Failure of Internal Control Systems" Journal of Finance 48: 831-880.

29. Jensen, M. C. 2005. “Agency Cost of Overvalued Equity” Financial Management 34 (1): 5-19.

30. Judge, G.G., R. C. Hill, W. E. Griffiths, H. Lutkepohl and T. C. Lee. 1988. Introduction to the Theory and Practice of Econometrics. New York, NY: John Wiley \& Sons Ltd.

31. Kumar, P. and K. Sivarmakrishnan. 2008. "Who Monitors the Monitor? The Effect of Board Independence on Executive Compensation and Firm Value" The Review of Financial Studies 21 (3): 1371-1401.

32. Lambert, R., D. Larcker and K. Weigel. 1991. "How Sensitive is Executive Compensation to Organizational Size?” Strategic Management Journal 12 (5): 395-402.

33. Larcker, D. F., S. A. Richardson, A. Seary and A. Tuna. 2005. "Back Door Links between Directors and Executive Compensation" available at: http://ssrn.com/abstract=671063 or doi: $10.2139 /$ ssrn.671063, (accessed 23 February 2011).

34. Larcker, D. F., G. Ormazabal and D. J. Taylor. 2010. “The Market Reaction to Corporate Governance Regulation", Stanford University Rock Center for Corporate Governance, available at: http://ssrn.com/abstract=1650333, (accessed 23 February 2011).

35. Li, F., and S. Srinivasan. 2010. "Corporate Governance When Founders are Directors" available at: http://papers.ssrn.com/sol3/papers.cfm?abstract_id=1663905, (accessed 23 February 2011).

36. Owusu-Ansah and G. Ganguli. 2010. "Voluntary Reporting on Internal Control Systems and Governance Characteristics: An Analysis of Large U.S. Companies." Journal of Managerial Issues 22 (3): 383-408.

37. Petra, S.T. and N. T. Dorata, N.T. 2008. "Corporate Governance and the Chief Executive Officer Compensation" Corporate Governance 8 (2): 141-152.

38. Ross, S. 1973. "The Economic Theory of Agency: The Principal's Problem" American Economic Review 63 (2): 134-139.

39. Shaw, K. W. and M. H. Zhang. 2010. "Is CEO Cash Compensation Punished for Poor Firm Performance?" The Accounting Review 85 (3): 1065-1093. 
40. Standard and Poor's. 2007. S\&P Compustat ExecuComp: The Executive Compensation Database. Englewood, CO: McGraw-Hill.

41. Wang, H., W. N. Davidson, III and X. Wang. 2010. "The Sarbanes-Oxley Act and CEO Tenure, Turnover, and Risk Aversion" The Quarterly Review of Economics and Finance 50: 367-376.

42. Wooldridge, J. M. 2002. Econometric Analysis of Cross Section and Panel Data. Cambridge, MA: The MIT Press.

43. Young, M.N. and A. K. Buchholtz. 2002. "Firm Performance and CEO Compensation: Relational Demography as a Moderator" Journal of Managerial Issues 14 (3): 296-313. 


\begin{tabular}{|c|c|}
\hline \multicolumn{2}{|l|}{$\begin{array}{l}\text { APPENDIX 1 } \\
\text { Variable Definition }\end{array}$} \\
\hline Variable & Definition \\
\hline TDC1 & $\begin{array}{l}\text { Total compensation comprised of the following: Salary, Bonus, Other Annual, } \\
\text { Total Value of Restricted Stock Granted, Total Value of Stock Options Granted } \\
\text { (using Black-Scholes), and Long-Term Incentive Payouts. }\end{array}$ \\
\hline Pay_Perform & The Difference between TDC1 and Salary plus Other Annual \\
\hline Log_Sales & Logarithm of total net sales \\
\hline Ret_3yr & $\begin{array}{l}\text { The } 3 \text { year total return to shareholders, including the monthly reinvestment of } \\
\text { dividends. } \\
\text { Total number of directors during the fiscal year }\end{array}$ \\
\hline $\begin{array}{l}\text { Board size } \\
\text { Comp Committee size }\end{array}$ & Total number of directors on the compensation committee during the fiscal year \\
\hline Board meetings & Number of board meetings during the fiscal year \\
\hline Comp Committee meetings & Total number of compensation committee meetings during the fiscal year \\
\hline CCSize_BdSize & Ratio of compensation committee size to board of directors size \\
\hline CCMeet_BdMeet & Ratio of compensation committee meetings to board meetings \\
\hline CEO_Chair & $\begin{array}{l}\text { Indicator variable set to one if the CEO is also the chairman of the board of } \\
\text { directors, otherwise zero }\end{array}$ \\
\hline OutDir_BdSize & Ratio of number of outside directors to board of directors size \\
\hline
\end{tabular}


NOTES 